\title{
The Leadership Traits Shared by Successful Entrepreneurs
}

\author{
Michael Glauser (My New Enterprise) \\ Dan Holland (Utah State University)
}

\section{KEYWORDS: Entrepreneurship, Management, Leadership, student entrepreneurs, Student innovators.}

This paper is based on a research process used by social anthropologists while investigating a new cultural phenomenon. It involves walking the streets, peeking around corners, observing practices, conducting indepth interviews, recording oral histories, and analyzing a rich description of a complex human process. This methodology puts the researcher much closer to realworld conditions, and sets the stage for future work. The conclusions in this paper are based on several hundred oral histories of successful business founders. The entrepreneurs include male and female business founders from various ethnic backgrounds who operate regional, national and international companies in the full spectrum of industries: manufacturing, high tech, petrochemical, transportation, wholesale, retail, service, health care, real estate, entertainment, restaurants, food service, and the arts. The companies have moved beyond the sole proprietorship stage: they are expanding operations, creating jobs, hiring employees, increasing revenue, paying taxes, and gaining market share in their industry.

Through a detailed content analysis, factors were identified that appear to have had a significant impact on the success of each company. Categories were created to represent the factors, and then collapsed through an iterative process into key principles common to a majority of the ventures. Thus, rather than fitting data into a preconceived framework for success, the final set of practices and resulting leadership model emerged from the histories of a broad and diverse group of successful business builders. The model has obvious implications for aspiring entrepreneurs, corporate executives, government leaders and researchers in the field of entrepreneurship.

\section{ENTREPRENEURIAL LEADERSHIP PRACTICES}

The eight leadership behaviors that consistently appeared in entrepreneurs' success stories are depicted in the model below.

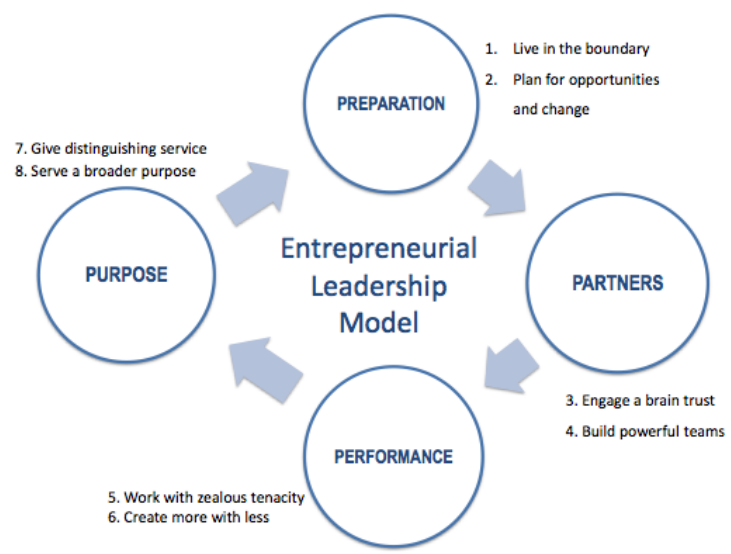

The practices are organized around four leadership processes: preparation, partners, performance and purpose. First, half the battle is won through preparation prior to the launch. Many new ventures that fail have been launched prematurely - before the entrepreneur has developed a sound understanding of customer needs and adequately tested his or her assumptions about the business. Second, finding the right partners, mentors, advisors and team members is a vital part of overcoming the pitfalls of venture creation. Third, working with great passion and tenacity, and developing distinctive resourcefulness, are critical to successful company performance over time. Finally, entrepreneurs who maintain a crystal-clear purpose of serving customers and the broader community seem to do better than those who lack this focus. Here's a more detailed summary of the eight practices depicted in the model.

\section{PREPARATION: Live on the Boundary}

The vast majority of the successful entrepreneurs that were interviewed have previously worked in the industry in which they started their business. Dimo Domov researched a large database of entrepreneurs and found that industry experience increases the confidence 
in new opportunities and has a direct positive effect on venture emergence. ${ }^{[1]}$ The Kauffman Foundation recently interviewed a number of 2015 EY Entrepreneur of the Year award winners and found that $74 \%$ of the entrepreneurs had previous experience in the industry in which they started their new venture. ${ }^{[2]}$ Of the entrepreneurs that we interviewed, those who haven't held a job in their industry were often serious and frequent consumers in that industry. Living on the boundary of the industry exposes future founders to the needs, products, services, suppliers, competitors, key customers and delivery systems. Also important, being in the thick of the action gives aspiring entrepreneurs ideas to contemplate and test while still drawing a paycheck. In nearly every success story, this "higher level of knowing" reveals the missing piece that leads to the business opportunity. Here are two typical examples.

Bill Kilburg, founder of Hospitality Performance Network (HPN), spent 17 years in the hotel industry as a bellhop, a financial assistant, a controller, and a CFO. After buying 22 hotels of his own, he saw weaknesses in the sales companies that were booking his facilities; he knew he could do a better job linking businesses with meeting sites and hotel rooms. Therefore, he started HPN to create a sourcing platform that focused on efficiency and relationships between his company and the hoteliers. Those relationships allow HPN to respond quickly with accurate bids to any requests for proposals from businesses seeking hotels or meeting space. ${ }^{[\mathrm{A}]}$

Likewise, Michael Hyacinthe spent nine years in the military prior to creating Urban Liberty, a fashion company that caters to men and women serving in the armed forces. The idea germinated while Michael was overseas and had difficulty finding "off-hour" clothing that represented his New York culture. He has partnered with the military to open stores on bases around the world, as well as a retail website, where military personnel can acquire the latest leisure fashions while serving abroad.

Living on the boundary is not only important to discover an opportunity and start a new venture, but it is also a critical component of growing the business. All organizations exist in geographical space; the center is the furthest away from customers. The boundary is the place where customers and products interface. Living on the boundary, rather than in a center office, provides first-hand and up-to-date information about new innovations, reactions from consumers, tactics of competitors, changing conditions and new business opportunities. Employees may be able to provide much of that information but subordinates may be resistant to sharing negative feedback with the founder.

Abraham Lincoln, one of America's finest presidents, is a superb example of "living on the boundary" in the political arena. According to Lincoln, the best way to assess an opportunity was to gather data personally. During his first few years in office, Lincoln spent more days out of the White House than he did in it. $\mathrm{He}$ inspected every state regiment that passed through Washington, D.C. He spent time with the troops in their encampments. He visited the wounded in hospitals. He met with cabinet members in their offices and generals in the field. He frequently spent his days in the telegraph office at the War Department to obtain real-time information. He studied new weaponry and even took charge of several battles, coming under fire on several occasions. This approach gave Lincoln first-hand information for important decisions and effective strategies without having to rely on second- or thirdhand information from others. ${ }^{[3]}$

In like manner, successful entrepreneurs spend a considerable amount of time on the edge of their organization - rather than in the center - gathering market information for decision making and strategic planning. Carl Winefordner and Frank Hermansen, founders of Crank Brothers, are superb examples of this practice. Carl is a mechanical engineer and Frank is an industrial designer - both are avid cyclists. Together they have created elite, state-of-the-art bicycle parts including pedals, wheel sets, seat posts, pumps and tools. Most of their products have been "born out of frustration" while riding together and with other cyclists. Carl believes "it is very difficult to create great products in an area in which you don't personally participate." They sum up their attitude by arguing "Above all, we are impassioned people; our work is our life and we live our work. This in itself is what ignites and makes every idea and product a reality."

Becky Anderson, founder of For Every Body, is another highly successful entrepreneur who spends most of her time gathering critical information about her industry, competitors, suppliers and customers. Becky says:

"You absolutely have to know your industry. These are questions I ask myself every Monday morning: What 
do I know today about a competitor I did not know last week? I spend hours and hours on all my competitors' websites, studying what they do, what promotions they have, what's working, what's not working, and what press releases they are putting out. What do I know this week that I didn't know last week about my customers? I read three newspapers a day and stay glued to CNBC since most of our customers are publicly traded. I like to know exactly what they are doing. What do I know about our top ten, twenty or thirty customers? What have I learned about them this past week? What do I know this week that I didn't know last week about my industry as a whole? What do I know this week that I didn't know last week about the social, cultural and economic trends that will affect our industry?"

Becky's knowledge of her industry has led to phenomenal relationships with customers, suppliers and industry leaders, and has helped For Every Body become one of the largest and fastest-growing candle manufacturers in the United States. Most of the entrepreneurs who were interviewed shared a similar sentiment about "working in the field," "staying on the boundary" and "living on the edge." Those who retreat deeper and deeper into the center of their organization often lose their way with market realities and cannot respond fast enough to changing conditions. In this chaotic business environment, those responsible for company direction and strategy need to reside in the boundary of their organization - where their customers, products and competitors meet. Doing so tends to reduce the level of uncertainty that is inherent in new venture creation.

\section{PREPARATION: Plan for Opportunities and Change}

While working in an industry, future entrepreneurs often stumble onto a business opportunity. Some present it to their current employer. A common response is: "We don't do that around here" or "That's not the business we are in." Aspiring entrepreneurs continue to massage the idea until they have a handful of potential customers and feel confident that the venture will work. Sometimes customers even commit to patronize the new business before it is launched; occasionally, customers become partners. Compare this scenario to the wannabe entrepreneur who quits a job, conjures up an idea outside an industry, and tries to push it into unknown terrain. A sound opportunity consists of:
1. A proposition for satisfying an unmet need (or a better way to meet a need)

2. A credible position in the industry (broad and deep industry knowledge/experience)

3. Access to the resources required to implement the proposition (suppliers, partners, funds, etc.)

4. A group of customers who are ready to buy the product or service right now!

A careful analysis of the thriving entrepreneurs showed that they continue to (1) develop related products and services to sell to their existing customers and/or (2) utilize their existing resources (team members, plants, technologies, funds, etc.) to cultivate new but related business opportunities. In other words, they do not remain stagnant. This tendency to create an assortment of new value propositions within an industry provides multiple streams of revenue and reduces the vulnerability of a single product or service.

Business founders apply shorter-term planning that is opportunity driven. They continue to amend a "portfolio of products and services" based on feedback from customers, tactics of competitors, new technology, and missing pieces in the marketplace. It's like they are running a test kitchen in tandem with their core business; and there is always something cooking in the kitchen. Sometimes these new recipes become the primary product or service for the organization. For example, Becky Anderson opened a retail bath and body shop, started making her own products, began selling her products to other retailers, and ultimately became one of the largest candle manufacturers in the country. June Morris, the only female to own and operate a major airline, started her career as a travel agent, launched a travel agency, built a leisure travel business, started an air charter company, and evolved into a full-fledged airline - which she sold to Southwest Air for $\$ 139$ million. ${ }^{[4]}$ Mimi Silbert, founder of the Delancey Street Foundation, continually asks herself, "What can I do with the resources I have" - which are convicted felons in the prison system. Mimi and her convicts have created more than 20 successful, laborintensive businesses including a moving company, a construction company, an auto detailing business, a furniture-making factory, Christmas tree lots, etc.

For many entrepreneurs, this process has occurred organically from being in an industry. With others, the process has become explicit and can be articulated. Chris Mittelstaedt, founder of The Fruit Guys, put it this 
way:

"I consider our business a constantly evolving research and development project. We are constantly looking for new opportunities. I actually have an employee who is my right hand person whose title is Manager of Special Projects. Her whole job is to work with me to develop everything new we are looking at. Some of it works out and some of it doesn't work out."

Bill Freedman, co-founder of DownEast Outfitters, espouses a similar strategy. DownEast started retailing "off-price" clothing, created its own brand, opened scores of stores, and then launched a home furnishing business after seeing an opportunity to apply their offprice model in a related industry. Bill stated:

"We feel like there is tremendous opportunity and a lot more growth potential. The baby, in our minds, still feels like an infant at every stage - that entrepreneurial spirit is alive and well. We test markets and do everything in a very measured way, and when we get a good bite on that hook, we set it hard. When the water gets rough, we back out, evaluate, and go a different direction. We are focused on opportunity, not clothing or furniture. We will continue to go after emerging markets and grow the business."

So winning entrepreneurs continue to seek out and plan for new opportunities that meet the needs of their existing customers and utilize their existing resources; they end up juggling a reasonable number of balls in the same or related industries. This process is consistent with the concept of "effectuation" introduced by Saras Sarasvathy in her groundbreaking research on entrepreneurial expertise. ${ }^{[5]}$ According to Sarasvathy, effectuation is the inverse of causation. In the causal model, the actor begins with a specific outcome to achieve, and then seeks out means to produce that exact outcome. With effectuation, the actor starts with a given set of means (who I am, what I know, who I know, what resources I possess) and seeks to create new ends using nonlinear and non-predictive strategies. It is not uncommon to hear entrepreneurs to make comments like: "I can't believe this all happened." "This isn't what I started out to do." "This is a glorious accident." "Our business today looks nothing like our original business plan." Effective entrepreneurs plan for new opportunities that arise and make necessary adjustments based on feedback from the market.

\section{PARTNERS: Engage a Brain Trust}

We discovered that effective entrepreneurs receive support from a handful of mentors during the launch of their business. These advisors provide the gentle nudge aspiring business builders need to "go for it!" Many entrepreneurs confessed they would not have started their exhilarating ride without the encouragement of one or more mentors. For example, June Morris received tremendous encouragement from her husband Mitch; Bill Kilburg was mentored by two of his employers; and Chris Mittelstaedt received great advice and a $\$ 20,000$ loan from his father - the dean of the business school at Arizona State University.

Successful entrepreneurs seek out a brain trust of mentors with certain qualifications that may help jump start any phase of the business by offering advice, providing resources, overcoming road blocks, and introducing important contacts. First, they typically know the entrepreneur fairly well. Obviously, mentors who understand a person's strengths and weaknesses will be in the best position to provide targeted assistance. Second, great mentors are enthusiastic about the business opportunity. They are excited about the idea, the products and services, and the entrepreneur's ability to make the venture work. Third, the most effective mentors have the skills and experience to fill a specific gap in the entrepreneur's knowledge - e.g. one mentor may understand the industry well, another may know financing options, and a third may be a marketing guru. Due to their experience, they are often able to see issues, obstacles, and opportunities that the entrepreneur may not recognize. Finally, helpful mentors have numerous contacts with people in the industry, people in related industries, people with money, people with similar ideas, and so forth. Such relationships are invaluable resources in the startup process.

\section{PARTNERS: Build Powerful Teams}

Examination of the interviews suggests that successful entrepreneurs thrive on the experience of others, are not threatened by team members who know more than they do, and enjoy building heroes other than themselves. They have a strong sense of who they are, what they do well, where they fall short, and where they best fit. As their venture grows, they recruit talented people to meet the needs of the business. Most important, they share ownership (stock, options, profit sharing, etc.) so team members are energized to excel at the highest level. They seem to be willing to accept a smaller piece of a 
bigger and better pie, rather than hold on to all of a smaller, half-baked pastry. They understand that partners will not act like owners unless they are treated as owners. In contrast, business builders who do everything themselves and hold on to all the upside, struggle to get the venture off the ground or get stuck on an early "sole-proprietorship" plateau. A talented team working together will always accomplish more in a shorter period of time than any individual working alone.

The Rubio family, founders of Rubio's Fresh Mexican Grill, were very good at making and selling fish tacos from a defunct hamburger stand near Mission Bay in San Diego; they were not skilled at building a restaurant chain. They realized their weakness and brought in a first-class team of food-service veterans with experience at Taco Bell, El Torito Grill, Las Salsa and Rally's Hamburgers. This team has grown Rubio's to 180 stores with over 50 million fish tacos sold - a feat the Rubio family could not have accomplished on their own. [6]

Bryce Phillips, founder of EVO, has followed a similar path. As a professional skier, he was excellent at selling gear on eBay and on his website, evogear.com. However, after achieving \$3 million in sales, he realized he was stuck:

"We were like pedal-to-the-metal entrepreneurs and didn't have the kind of experience that rock-solid retailers do. We realized that if we wanted to become a world-wide brand, we had to bring in the right kind of leadership. So we've got an amazing new president with 12 years at $R E I$ (she ran the finance team and the marketing group), an amazing COO who ran all operations at Lands End (technology, customer care and logistics), and a great board of directors."

Chris Michel, founder of Affinity Labs - a company he sold to Monster, Inc. for $\$ 80$ million after just 14 months of operation - is a master team builder. He attributes his success to bringing together "a really great group of people on a pretty good problem and working hard at it." He described his attitude toward team building in a recent interview:

"One key to success is having a very small and overqualified team. We all know this, but forget that the best people could also go and be CEOs at their own companies. In a "war for talent" you have to ask yourself: What wouldn't you do to bring the right people onto your team and keep them in the game?"[7]

In addition to building a powerful management team, thriving entrepreneurs develop strong partnerships with critical players outside of the company. Bryan Morgan, founder of Adventure Life, achieved $\$ 11$ million in sales in 2008 in a very difficult and competitive industry. He attributes his success to the partnerships he has developed with guides and operators throughout Latin America. He finds partners with similar values, develops trusting relationships, and relies heavily on their expertise. These partnerships have allowed him to dramatically expand his customer offerings without taking on additional overhead. Similarly, the Freedman brothers at DownEast Outfitters owe much of their success to the exceptional partnerships they have developed with top-of-the-line clothing and furniture companies. While building effective partnerships is difficult, successful entrepreneurs work at it constantly.

\section{PERFORMANCE: Work with Zealous Tenacity}

Successful entrepreneurs are high-energy people. They have two related and vital qualities: zeal for their business and dogged tenacity to win. Zeal is a joyful, enthusiastic, and eager pursuit of some outcome or activity - it is synonymous with passion. Rick Burns, founder of Steeplechase films, told us about the power of zeal that radiates from successful entrepreneurs:

"You see it in their actions; you hear it in their voice. And the same thing that compels them becomes part of their ability to make it compelling to you. You're drawn to it like a moth to a flame. And that enthusiasm becomes the central fuel that propels the project forward. It grows like a series of concentric circles."

So zeal is the fire that drives the venture: it attracts members to the team, helps secure funding, entices customers to buy, and allows the startup to compete with the giants. Zeal is energy! Zeal is infectious! Zeal is power! It is not possible to start and grow a thriving company without a hearty dose of zeal.

Successful entrepreneurs also possess a teeth-gritting tenacity that will not quit. They find ways to get over mountains, across valleys, over hurdles and around road blocks; they simply will not take "no" for an answer. This often involves working long hours, whittling away at challenges, keeping costs down, 
changing directions and starting anew. As Brian Chesky, co-founder of Airbnb explained about the creation of his company:

"While we lived together, we decided to wake up at 8 a.m. and sleep at 12 a.m. and only work in between nothing else. We did this for 4 months and completely dedicated ourselves to Airbnb."[8]

Marti McMahon, founder of Pacific Marine Yachts, is also an excellent example of zealous tenacity. Marti has three great loves: boats, people and entertainment. She combined these passions in her business - a company that offers gourmet dining during scenic cruises of the San Francisco Harbor. Marti bought her first boat in Florida, then sailed it through the Panama Canal and on to San Francisco with her three small children. They survived a major storm, a month of boat repairs, fights with Mexican customs, food poisoning, and the company of a bedraggled crew. While refurbishing her boat she dealt with a divorce, a mother with cancer, and loan rejections from 13 banks. Yet, over time, Pacific Marine Yachts developed into a company with multiple vessels anchored at Pier 39, dozens of employees, and delivers 5-star service to many of the bay area's biggest corporations. Marti's zealous tenacity was essential to the success of her venture.

\section{PERFORMANCE: Create More with Less}

The prosperous entrepreneurs in our study are masters of resourcefulness. They create new ventures from practically nothing, get more from less along the way, and keep costs well below industry standards. These leaders have a real knack for finding and utilizing a host of resources other than money: they use old furniture in the office, defer compensation, partner with their first customers, negotiate excellent terms, and use someone else's plant rather than build one. Elon Musk, founder of Pay Pal, Tesla Motors and SpaceX, describes this process during his early days at Pay Pal:

"When you are first starting out you really need to make your burn rate ridiculously tiny. I had very little money so there really wasn't any choice ... Then my brother came down and he had a few thousand dollars. We rented an office for four or five hundred dollars a month - a really tiny little office in Palo Alto, which was cheaper than an apartment. We bought futons that converted into a couch, which was sort of like a meeting area during the day. We would sleep there at night and then shower at the YMCA which was just a few blocks away." [9]

When developing a new product, entrepreneurs tend to create a very low cost prototype, test it, and prove that it works before investing large sums of money. Once a model is proven, it is much easier to raise money to scale the business; and the entrepreneur has more leverage when negotiating with investors. Startup companies that have a lot of money tend to spend it; new ventures that don't are forced to find customers and generate sales. In other words, they are frequently funded by customers rather than by investors.

Josh Coates has created two software companies, Scale Eight and Mozy. With Scale Eight, he raised \$60 million, bought nice furniture, purchased elaborate signage, launched expensive marketing campaigns, grew to 200 employees, and opened offices in San Francisco, New York, Virginia, Tokyo and London. After four years, the company sold its patents to Intel and closed its doors - a modest business success, but a financial disappointment. In 2005 Josh started Mozy, a provider of online backup data solutions. In this venture, he leveraged the lessons he learned from Scale Eight: he raised very little money, created a working model, and focused on customers and sales. Two years after inception, he had 300,000 customers and sold the company to EMC for $\$ 76$ million. Josh described the lessons he learned in a recent interview:

"Too much funding makes you stupid. If you have an enormous amount of funding you tend to spend it ...There is an expectation that if you don't spend it you're not doing your job...(With Mozy) I did everything differently...I did my homework and took the time to come up with the right model. I raised very little money, and I drove the boat myself ...After your business machine starts working, you can step on the gas. But if you are not even sure your car runs, it's not a good idea to get on the freeway."

Furthermore, the lessons learned from early bootstrapping often carry over to the growth phase of the business. This sharp eye for getting more from less renders a tremendous competitive advantage over big bureaucratic competitors.

\section{PURPOSE: Give Distinguishing Service}

Customers have a set of expectations when they patronize a business. If these expectations are not met, they become frustrated, tell all their friends, and tend to 
avoid that business. When customers' expectations are met, they are generally satisfied with the experience. The problem is, satisfied customers are not always loyal customers - they may patronize a competitor's company next week. To obtain true loyalty, business owners need to exceed customers' expectations, offering them far better service than they thought they might receive. One of the primary ways that entrepreneurs are able to develop a competitive advantage is through an intense customer focus with which they are able to gain genuine insights into people's needs. As they strive to uniquely fill those needs, customers are pleasantly surprised by the value of the product or service, tell all their friends, become fiercely loyal to the company, and stop going to competitors' businesses; in essence, they become partners with the company.

Steve Thomas and Stephanie Greenwood are the founders of Bubble and Bee, a company that produces the highest quality organic personal care products. Steve and Stephanie's major focus is to provide fabulous service to a community of customers who love their products. They provide a wealth of information on their website about ingredients used in the marketplace, and customers can chat with Stephanie personally by phone or online. The company will customize products for specific customers, replace any product that doesn't work, and even provide recipes so customers can make the products at home. To accommodate this request, Bubble and Bee sells kits that contain the ingredients used in their products. While some customers still try to make their own soap, deodorant or shampoo, most end up buying the products from the company. Customers have become fiercely loyal to the company and it is growing rapidly. Executives at Whole Foods, one of Bubble and Bees' distribution partners, feel the company can become the next Burt's Bees.

In addition to offering distinguishing service early on, successful entrepreneurs establish systems for maintaining exceptional service as the business grows so customers will have the same experience regardless of who serves them. This is difficult to achieve as a growing company places more and more demands on the founders. It's all about priorities and focus. Chris Mittelstaedt of The Fruit Guys realized his team members did not always embrace the same concept of service that he did. He created a system called the " 5 Rs" to educate his employees and give them a tool to assess their performance. This system puts everyone on the same page when interacting with customers:

Respectful: Have we been respectful to all people we interact with?

Responsive: Have we been responsive to their needs?

Realistic: Have we been realistic about what we can and cannot do?

Responsibility: Did we take responsibility for the outcome?

Remembered: Are we going to be remembered positively?

One interesting note about entrepreneurs that permeated from the interviews is that their desire to offer distinguishing service is not driven by making more money. Remember, they start their ventures to satisfy an unmet need they have discovered in a marketplace. The entrepreneurs have a passion for meeting this need better than anyone else in their industry. Over and over we heard statements like: "I want to do something great for people; I love serving our customers; We want to be the best; I want to be a vital contributor." When making lots of money is the major motivation, companies often cut corners to increase profits, which may hurt them later. When serving customers better than anyone else is the driving force, companies are more likely to gain and keep customers as partners. It is much easier to tweak the numbers when you have a large customer base that loves you than it is to make money when your customers don't think you are anything special.

\section{PURPOSE: Serve a Broader Purpose}

Many of the successful entrepreneurs that were interviewed are passionate about the double bottom line: what the company earns and what the company contributes to the larger community. The story typically goes like this: "I never thought I would be so successful. It's our customers who have gotten us where we are today. I would really like to do something to show our appreciation for this community." The result: these entrepreneurs are supporting schools, disseminating health information, lowering grocery costs, helping families of the chronically ill, feeding the hungry, aiding the homeless, and funding cancer research. Before long, community members begin to reason: "This business supports us, let's support this business." So generosity endears the 
community to the organization, which aids the survival and growth of the venture even though this was not the original intent of giving. Robin Petgrave, founder of Celebrity Helicopters, explains it this way:

"When I started this company I decided people would be more important than money. I knew I had to make money, but the money would go to creating jobs and doing stuff for the community. It's really twofold: one, the people you help really like it, and two, the news media loves it, which brings in more people to experience all the stuff you are doing. It's a cycle that feeds itself..." $[10]$

Entrepreneurs serve a broader purpose in several ways: some find a favorite charity or charities and provide donations and/or ongoing support; others partner with an organization that serves the same constituency; and some spin off a nonprofit organization to handle their charitable initiatives. In addition, most of the entrepreneurs who were interviewed are actively involved in speaking at schools, mentoring students, judging business plan competitions, helping other entrepreneurs, etc.

For some successful entrepreneurs, serving society is the overarching objective of the organization; it's more like they are starting a "movement" than a business. Blake Mycoskie, founder of TOMS Shoes, wanted to provide shoes to needy children in South America. He started a for-profit business, rather than a nonprofit, to improve long-term sustainability. He explained his reasoning:

I thought I could actually create a more sustainable way to give shoes to people by being a for-profit business that was based on this "buy one give one" model. I really worried about starting a charity and being dependent on people's donations. Let's say I went to my parents and friends and family and they give me money the first year, and I gave the shoes away. And now the second year and the kids are getting used to wearing shoes. Then we have something like hurricane Katrina and I go to my donors and they say, "Blake we love what you do and you're really passionate, but we gave our money this year to Katrina victims. Now, what do I tell the kids? So my idea was to create a business (in order to) have true sustainability. And we've proven that it works. You don't have to start a charity to really help people; you can start a business and help far more people. ${ }^{[11]}$
Jon Huntsman, founder of Huntsman Chemical - a global petrochemical company - is perhaps the definitive example of this "serve a broader purpose" philosophy. He has donated more than $\$ 1.2$ billion during his lifetime, giving him a place among only 19 billionaires to have donated $\$ 1$ billion or more. ${ }^{9} \mathrm{He}$ explains it this way:

"Our bottom line is the utilization of profits to enrich the human soul and alleviate human suffering. We always try to combine a humanitarian project that will genuinely help the people with our business interests. It might be assisting the flood victims in Thailand or the homeless in Armenia, or helping to relieve starvation in Russia, India and Ukraine. Until we move beyond the profit level and help find cures for cancer, provide for the homeless, and feed the poor, we haven't achieved our corporate objectives."

Of course, the business must be sound in order to support community endeavors. An entrepreneur can't be a big-hearted soul and a lousy businessperson or there will not be anything to share. The first seven practices reviewed above are vital to implementing this step. Though many entrepreneurs have developed this practice over time, thriving entrepreneurs tend to seek both business success and opportunities to benefit their community. And when one pursues a cause bigger than oneself, more people jump on the bandwagon. This aspect of new venturing has become more and more critical in attracting the rising "Millennial Generation" as potential customers and employees as they seem to place significant emphasis on corporate social values, social responsibility and service to the community. In fact, $87 \%$ of Millennials said that "the success of a business should be measured in terms of more than just its financial performance." 10

\section{SUMMARY}

More people than ever have the desire to start their own business, create new jobs, introduce novel products and services, innovate technologies and stimulate our economy. Understanding and emulating business builders is critical to our future economic prosperity and competitive advantage as a nation. Years of interviews, observations, and case analyses have revealed a handful of common practices used to develop successful businesses. Thriving entrepreneurs

- have a broad and deep understanding of the 
industry in which they operate, which usually comes from having worked in that industry.

- create unique products and services that meet a need that is either not being met or not being met very well; they don't create "me-too" products.

- continue to live on the boundary of their organization where products and customers interface, giving them first-hand experiences for product development and strategic planning.

- continue to explore and develop new products and services that maximize their existing channels of distribution as well as the resources they control, which is a shorter-term, nonlinear planning and development process.

- rely on a select number of mentors, advisors and other entrepreneurs to jump start and fast track their new venture.

- build teams of talented people who fill in the gaps in expertise and experience, and then create upside for this team of colleagues.

- develop long-term partnerships with other companies that can move their venture forward - they tend to think "partners" first, rather than worry too much about "competitors."

- emulate remarkable zeal for their business, which attracts team members, investors, partners and customers to the new venture.

- possess unflinching tenacity, which drives the venture forward and helps them conquer the rocky road of new venturing.

- orchestrate marvelous efficiencies in funding, management, sales and marketing - they think resources first, money second - which gives them a strong competitive advantage in their industry.

- focus on meeting a unique need in a marketplace better than anyone else, and create systems to maintain distinguishing service with every customer.

- serve the broader community in which they reside, which leads to beneficial relationships, positive visibility and more business for their organization.

The Entrepreneurial Leadership Model presented in this paper has relevance for all types of organizations. It doesn't matter if you are launching a new venture, running a large corporation, managing a nonprofit, working in government or administering a school. Every leader needs to prepare for opportunities, find the right partners, orchestrate effective and efficient performance, and maintain a crystal clear focus on what matters most. In this era of turbulent change, the practices of successful entrepreneurs can benefit any organization.

\section{References}

[A] Please note that all of the examples and quotes used in this article are taken from the first author's personal interviews with the entrepreneurs, unless otherwise noted.

[1] Dimov, Dimo. (2010), Nascent Entrepreneurs and Venture Emergence: Opportunity Confidence, Human Capital, and Early Planning. Journal of Management Studies, 47: 1123-1153.

[2] Amisha Miller \& Colin Tomkins Bergh. "A Snapshot of the Emerging Entrepreneur." 12 Nov 2015.

[3] Donald Phillips, Lincoln on Leadership (New York: Warner Books, 1992), 13-25.

[4] Michael Glauser, Glorious Accidents: How Everyday Americans Create Thriving Companies (Salt Lake City: Shadow Mountain Publishing, 1998), 258-264.

[5] Saras Sarasvathy, Effectuation: Elements of Entrepreneurial Expertise (Cheltenham: Edward Elgar Publishing, 2008).

[6] Michael Glauser, Glorious Accidents: How Everyday Americans Create Thriving Companies (Salt Lake City: Shadow Mountain Publishing, 1998), 195-196; www.Rubios.com(http://www.Rubios.com)

[7] Interview with Chris Michel, founder of Affinity Labs, on the GigaOM Network, June 2008.

[8] McCann, Chris. "Two Tech Billionaires Just Interviewed Each Other in My Stanford Class - Here's What They Said." Business Insider. Business Insider, Inc, 20 Nov. 2015. Web. 06 May 2016, http://www.businessinsider.com/linkedin-cofounder-reid -hoffman-interviews-airbnb-founder-brian-chesky-atstanford-class-2015-11

[9] Interview with Elon Musk, cofounder of PayPal, by Knowledge@Wharton, May 2009; http://knowledge.wharton.upenn.edu/article.cfm?articlei $\mathrm{d}=2245 \#$

(http://knowledge.wharton.upenn.edu/article.cfm?articlei 
$d=2245)$

[10] Michael Glauser, Glorious Accidents: How Everyday Americans Create Thriving Companies (Salt Lake City: Shadow Mountain Publishing, 1998), 229-236.

[11] Interview with Blake Mycoskie, founder of TOMS Shoes, at the 2009 Clinton Global Initiative Conference, http://www.youtube.com/watch?v=UCNOMJHmfDg\&fea ture=channel

9 Whelan, David. "Jon Huntsman On Giving Away $\$ 1.2$ Billion." Forbes. Forbes Magazine, 18 May 2011. Web. 30 Apr. 2016

10 "Millennial Survey 2016." Deloitte. Deloitte, 21 Jan. 2016, Web. 30 Apr. 2016. 